\title{
Analysis and Monitoring Results of a Building Integrated Photovoltaic Façade Using PV Ceramic Tiles in Taiwan
}

\author{
Yen-Chieh Huang, ${ }^{1}$ Chi-Chang Chan, ${ }^{2}$ Szu-Chi Kuan, \\ Shui-Jinn Wang, ${ }^{1,3}$ and Shin-Ku Lee ${ }^{4}$ \\ ${ }^{1}$ Institute of Microelectronics, Department of Electrical Engineering, National Cheng Kung University, Tainan 701, Taiwan \\ ${ }^{2}$ Green Energy \& Environment Research Laboratories, Industrial Technology Research Institute, Hsinchu 310, Taiwan \\ ${ }^{3}$ Advanced Optoelectronic Technology Center, National Cheng Kung University, Tainan 701, Taiwan \\ ${ }^{4}$ Research Center for Energy Technology and Strategy, National Cheng Kung University, Tainan 701, Taiwan
}

Correspondence should be addressed to Shin-Ku Lee; sklee1015@gmail.com

Received 21 February 2014; Accepted 1 May 2014; Published 6 July 2014

Academic Editor: Sudhakar Shet

Copyright (C) 2014 Yen-Chieh Huang et al. This is an open access article distributed under the Creative Commons Attribution License, which permits unrestricted use, distribution, and reproduction in any medium, provided the original work is properly cited.

Single-crystal silicon-based solar cells laminated with tempered-glass and ceramic tiles for use in a building's façade have been developed. The optical, thermal, and electrical properties of the proposed PV module are first evaluated, and then a wind-resistance test is carried out to evaluate the feasibility of installing it in Taiwan. The electrical and deflection characteristics of the proposed PV module did not change significantly after a 50 thermal cycling test and a 200-hour humidity-freeze test, based on IEC 61215 and a wind-resistance test. Finally, the electrical power generation ability of the proposed BIPV system with $1 \mathrm{kWp}$ electrical power capacity was examined. Building information modeling software tools were used to simulate the BIPV system and carry out the energy analysis. The simulation results show a very consistent trend with regard to the actual monthly electricity production of the BIPV system designed in this work. The BIPV system was able to produce an accumulative electrical power of $185 \mathrm{kWh}$ during the 6-month experimental period. In addition, the exterior temperature of the demonstration house was about $10^{\circ} \mathrm{C}$ lower than the surface of the BIPV system, which could reduce indoor temperature.

\section{Introduction}

The world population exceeded seven billion in 2012, presenting problems with regard to shortages of food and conventional energy sources. In addition, emissions of greenhouse gases (GHG), such as carbon dioxide, nitrogen sulfide, and fluorine carbonate, which are related to the burning of fossil fuels, are adversely affecting the environment and leading to a rise in global temperature [1]. Solar energy is a renewable energy resource that can be easily obtained and presents no problems with regard to pollution. However, there are still two main issues that hinder the development of the solar cell industry. One is the cost of generating electrical power per unit cell, which cannot compete with conventional electrical power production based on fossil fuels or nuclear energy. Another is the varied distribution of sun irradiation on the earth's surface, which makes it difficult to obtain sufficient solar energy at a reasonable cost in many places.

Most current solar cells use Si-based technology and can be divided into single-crystalline, polycrystalline, and amorphous-silicon ( $\alpha$-Si) types. Single-crystal solar cells have the highest efficiency of 16 to $24 \%$, with a maximum modular efficiency of $20 \%$. Polycrystal and $\alpha$-Si solar cells have efficiencies of 14 to $18 \%$ and 4 to $10 \%$, respectively. Although they have a lower photoelectron conversion efficiency compared with single-crystal solar cells, $\alpha$-Si and non-Si-based solar cells, such as CdTe, CIS, and CIGS, have the advantages of greater flexibility and transparency, as well as lower cost, and these qualities make them suitable for use in thin film technologies [2].

The use of the building incorporated photovoltaic (BIPV) systems is one of the most promising technologies with 
regard to the development of the state-of-the-art photovoltaic (PV) systems. Compared to traditional nonintegrated PV systems, BIPV not only requires no extra area to be allocated for the PV systems, brackets, or rails for installation, but also offers instant electrical power for buildings, supporting applications such as air conditioning and illumination. Due to these advantages, BIPV is likely to be one strategy for successful development of PV systems in the future [3]. A BIPV system can replace the traditional envelopes of buildings, like roofs, windows, façades, and shading systems, and thus this technology has attracted the interest of many architects. A BIPV system can also provide shade from the sun, reducing the heat absorbed by the building, thus saving energy and modulating the indoor temperature [4].

While many researchers are working to develop and apply BIPV systems, few studies have evaluated the various benefits associated with the use of integrated PV kits or the effects of such systems on the comfort of those using the related buildings. In order to obtain the maximum benefits with regard to shading effects, indoor temperature, photoelectron conversion efficiency, and indoor light intensity, Kim et al. combined a sensor-embedded motor-controllable louver with solar cells to assess the allocation ability and synergistic advantages of the proposed PV kits [5]. Peng et al. discussed either choosing BIPV or building-attached photovoltaic (BAPV) systems for practical use in China. Their study not only examined how to extend the lifetime of PV systems, but also considered the functionality, price, and fabrication techniques of such systems, as well as how they affected the appearance of buildings. Based on this, they designed a BIPV system whose PV kits can be easily retrofitted and maintained on existing buildings [6].

Yoon et al. integrated transparent $\alpha$-Si solar cells on a building's envelope in Korea and monitored the performance of the BIPV system for two years, with the results showing that it had electrical power throughputs of $48.4 \mathrm{kWh} / \mathrm{kWp} /$ month and $580 \mathrm{kWh} / \mathrm{kWp} /$ year. The location of the proposed PV system was inclined by $50^{\circ}$ in the southwest and masked by nearby buildings, and the resulting masking effect caused the below-average electrical power output compared to the findings of other studies. The results of a computer simulation, which consider both shading and the solar azimuth angle, showed that the energy generation efficiency could be increased by up to $47 \%$ by modifying the location of the BIPV building [7].

Wittkopf et al. constructed a zero-energy office building in Singapore, based on integrated PV modules, and evaluated the performance of the resulting grid-connected BIPV system over 18 months under IEC standard 61724. The results showed a good overall performance ratio and average array yield of 0.81 and $3.86 \mathrm{~h} / \mathrm{d}$, respectively. The final yield was $3.12 \mathrm{~h} / \mathrm{d}$, averaged over all arrays. The efficiency of the PV system was $11.2 \%$, and the array efficiency was $11.8 \%$, compared to the nameplate PV module efficiency of $13.7 \%$, while the overall inverter efficiency was $94.8 \%$. They also divided the solar irradiation into three levels and discussed the factors that can affect this, such as shading, solar azimuth angle, inclination, and temperature, based on some selected solar cell modules [8].
Santos and Rüther quantified the potential of BIPV and BAPV systems for use with existing single-family detached residential buildings in Florianopolis, Brazil. They compared the output performance of photoelectron conversion efficiency for thin film $(\alpha-S i)$ and single-crystalline solar cells. The proposed PV kits were installed on the roof tops of 496 residential buildings in a mixed residential-commercial area. The roof of a typical single-family, detached home can easily accommodate the proposed PV kits, with $87 \%$ of these generators yielding at least $95 \%$ of the maximum theoretical generation output. The low-pitched, available roof covers of such residential buildings represent ideal locations for PV integration at low latitudes, and installing BIPV on all of the existing roof areas would be able to transform each and every house into a net energy-positive building [9].

Yoon et al. examined how the increase in temperature on the glass surface of BIPV systems is related to the electrical power output. The results showed that the temperature of windows situated on both the horizontal and inclined planes increased significantly during the summer, with a high solar altitude. With regard to the indoor surface temperature of the windows caused by the thermal insulation effect of BIPV systems, which is closely related to the thermal comfort of the building's occupants, the surface temperature of BIPV windows with low solar heat accumulation was $1^{\circ} \mathrm{C}$ less than that of normal windows during daytime in summer and was about $2^{\circ} \mathrm{C}$ higher at night time during winter [10].

This paper examines the case of a BIPV demonstration house composed of PV ceramic tiles that was built at the Industrial Technology Research Institute (ITRI), Hsinchu, Taiwan, at $24^{\circ} 46^{\prime}$ north latitude and $121^{\circ} 02^{\prime}$ east longitude, with the PV module on the vertical wall of the experimental house facing west. First, the optical, thermal, and electrical properties of the proposed PV module are evaluated. A windresistance test based on the ASTM E330 [11] standard is then implemented to evaluate the material performance of the PV module using the architectural dry-suspended method. Finally, the BIPV system is directly hung on the vertical wall of the demonstration house to evaluate the in situ power generation. In addition, a powerful building information modeling (BIM) simulation technology is applied to the modeling and energy analysis of this BIPV system [12].

Since there are some unfavorable factors for widespread installation of BIPV systems. For example, the cost of PV modules is still too high, and a better design approach is needed so that cheaper architectural strategies can be used. In addition, more data needs to be obtained from computer simulations in order to design more energy efficient BIPV buildings.

The current study presents a simulation and energy analysis of a BIPV demonstration house using the BIM modeling software, the results of which can help to evaluate and improve the design of BIPV buildings. More specifically, the electrical power generation performance of the proposed BIPV system was investigated for a period of six months in Taiwan, and the data obtained from this can be used to develop better PV ceramic tiles for use in such systems. 

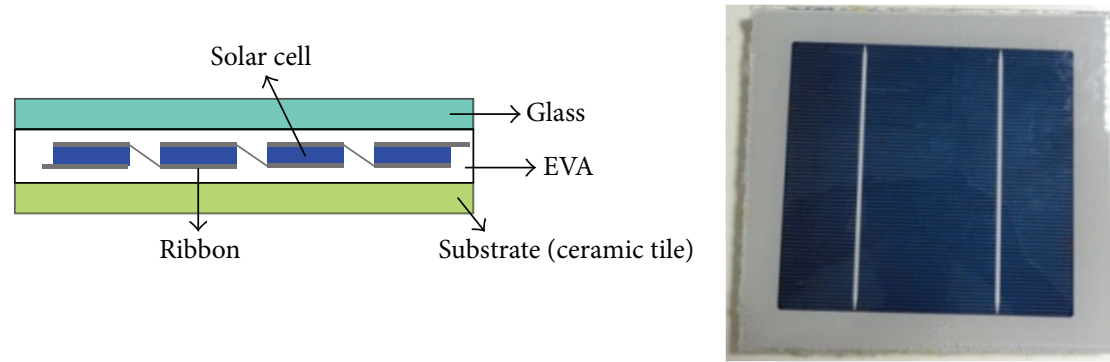

FIGURE 1: Schematic diagram of the proposed PV module.

\section{Experimental Setup}

2.1. PV Module Structure. A PV module consists of multiple components, including solar cells, mechanical and electrical connections, mountings, and means of regulating and/or modifying the electrical output. All the materials used in the module need to be resistant to water, electricity, and temperature. The structure of the single-crystal solar cells integrated with a ceramic tile is shown in Figure 1. The length, width, and thickness of the PV module are $40 \mathrm{~cm} \times 40 \mathrm{~cm}$ $\times 12 \mathrm{~mm}$, respectively, and this $\mathrm{PV}$ module is laminated between tempered-glass and ceramic tile substrate using an ethylene vinyl acetate (EVA) copolymer. The solar cells each are serially connected by copper conducting wires. The proposed PV module is finished when all the interconnecting circuits are completely connected to a connection box on the reverse side of the device.

2.2. Optical Property Measurement. UV-Vis absorption spectra are recorded using a Lambda 900 UV-VIS-NIR spectrophotometer (Perkin-Elmer, UK). Spectral transmittance/reflectance measurements of the samples are carried out to determine the optical properties in the spectral range of solar radiation and thus in the wavelength interval between $300 \mathrm{~nm}$ and $2500 \mathrm{~nm}$, based on ISO 9050 [13]. In addition, the emissivity of the samples is determined using an FTIR spectrophotometer (Perkin-Elmer, UK). The FTIR spectra are recorded in the range from $400 \mathrm{~cm}^{-1}$ to $4000 \mathrm{~cm}^{-1}$, with a resolution of $4 \mathrm{~cm}^{-1}$, and averaged over 25 scans.

2.3. Thermal Property Measurement. The small-sized hotbox test with a solar simulator lamp, designed in an earlier work [14], is used to evaluate the thermal performance of the PV module. The walls of the chamber are made of $0.05 \mathrm{~m}$ thick Styrofoam plates. The inner surfaces of the chamber are painted black to prevent light from being reflected and diffused away from the glass surface. A $1000 \mathrm{~W}$ xenon arc lamp is used as a solar simulator lamp to provide the incident radiant energy. The xenon arc lamp is positioned in order to achieve a homogenous distribution of radiant intensity across the whole surface area of the PV module. Six K-type thermocouples are used to measure the surface temperature on both sides of the PV module, and two K-type thermocouples are used to measure the exterior and interior ambient temperatures.
2.4. Maximum Power Determination. The maximum power determination tests are performed under standard test conditions, which correspond to $1000 \mathrm{~W} / \mathrm{m}^{2}$ at a cell temperature of $25 \pm 2^{\circ} \mathrm{C}$, with an air mass of $\mathrm{AM}_{1.5}$ solar spectral irradiance. To assess the performance of the samples under practical conditions, a 50 thermal cycling test and a $200 \mathrm{~h}$ humidityfreeze test based on IEC 61215 are carried out [15].

2.5. Wind-Resistance Test Procedure. Figures 2(a) and 2(b) show the solar cell arrays $(3 \times 4)$, with a size of $1,266 \mathrm{~mm} \times$ $1,670 \mathrm{~mm} \times 120 \mathrm{~mm}$, that are used to evaluate the windresistance characteristics of the proposed BIPV system using the architectural dry-suspended method. A wind resistance test based on the ASTM E330 standard is conducted in an approved test chamber at an accredited independent testing laboratory. Applying a test load spectrum allows the structural performance of a BIPV system subjected to an extreme wind event to be assessed. The specified load spectrum should contain a series of varying positive and negative pressure cycles that represent the wind behavior that affects buildings. Based on the mechanical load test in Section 10.16 of the IEC-61215 standard, $2400 \mathrm{~Pa}( \pm 800 \mathrm{~Pa})$ is used as the standard test condition for the PV module.

The uniform static air pressure differences $(P)$ acting inward and outward are related to the wind velocities $(V)$ and the Beaufort scale $(B)$ by $(1)$ and can be used to confirm to what degree actual wind disaster conditions are achieved:

$$
\begin{gathered}
V=0.836 \times\left(B^{3 / 2}\right), \\
P=k V^{2},
\end{gathered}
$$

where $k$ is a constant and the value is 0.124 in CGS units. Using wind pressure between $2400 \mathrm{~Pa}$ and $6400 \mathrm{~Pa}$, the specified load spectrum is divided into five varying positive and negative progressive pressurized phases. In each phase, the pressure is increased by $1000 \mathrm{~Pa}$, with each increase being one unit on the Beaufort scale. For the deflection measurement, three sets of displacement gauges are mounted at various locations along the longitudinal centerline of the windward and leeward surfaces of the PV module. A visual inspection based on Section 10.1 of the IEC-61215 standard is conducted to detect any cracking, bending, deformation, or damage occurring on the PV module in terms of the solar cell, connecting junction, and the critical looseness of the alumina frames. The critical defects which could significantly affect 


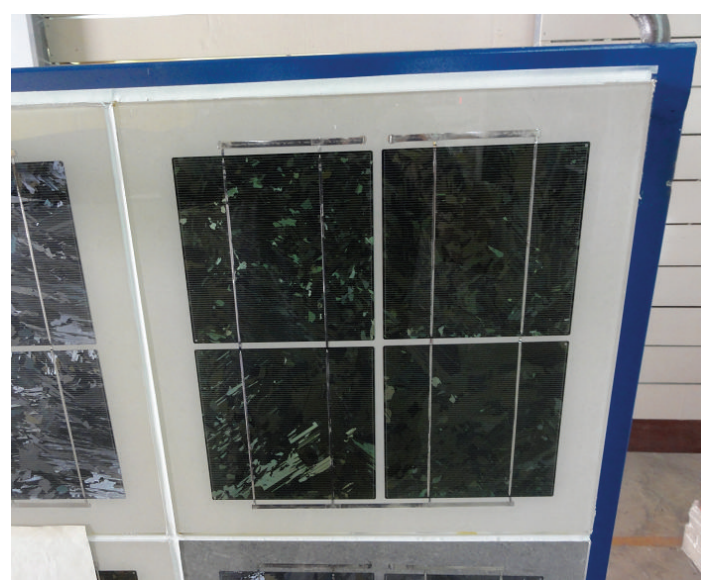

(a)

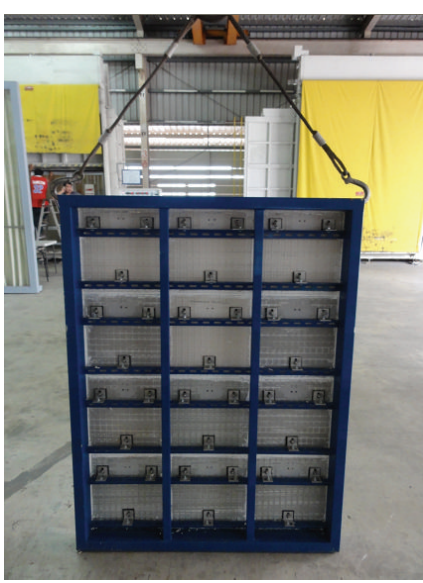

(b)

FIGURE 2: (a) Outward and (b) backward sides of the PV module.

the performance of the PV module are determined using a lamp with an illumination of not less than 1,000 lux.

The procedure for the wind-resistance test is as follows.

(1) Remove any sealing or construction material from the test specimen that will not be used when the assembly is installed in or on a building. Fit the specimen into or against the chamber opening. The outdoor side of the specimen is subjected to positive loads, and the indoor side is subjected to negative loads. Support and secure the specimen by the same number and type of anchors used when installing the unit on a building or, if this is impractical, by the same number of other comparable fasteners, located in the same way as in the intended installations.

Remarks. If the air flow through the test specimen is such that the specimen cannot be secured, then the cracks and joints through which air leaks should be sealed using tape or other means that will effectively stop this, although this should not restrict any of the movements of the specimen components. As an alternative, it is possible to cover the entire specimen and mounting panel using a plastic film with a thickness of $0.05 \mathrm{~mm}$. However, the technique used to apply this is important, in order to ensure that the maximum load is transferred to the specimen and that the plastic film does not prevent the movement or cause the failure of the specimen. The plastic film should be applied loosely, with the folds of the material at each corner and at all offsets and recesses. When the load is applied, there should be no fillets caused by the tightness of the plastic film.

(2) Check the specimen and adjust it if needed.

(3) Install any deflection measuring devices at the required locations.

(4) Apply $1 / 2$ of the maximum test load and hold for $10 \mathrm{~s}$. Release the pressure difference across the specimen and record the initial reading. The recovery period
(Pa)

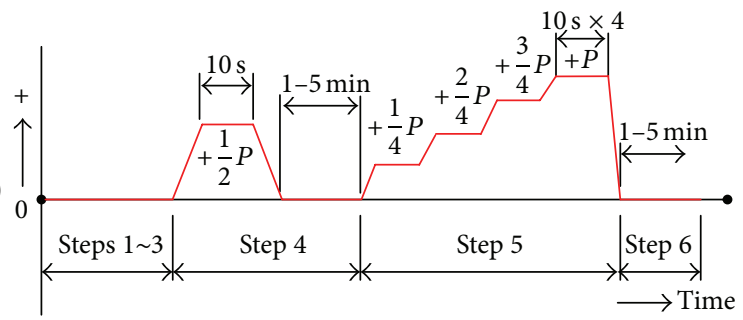

(a)

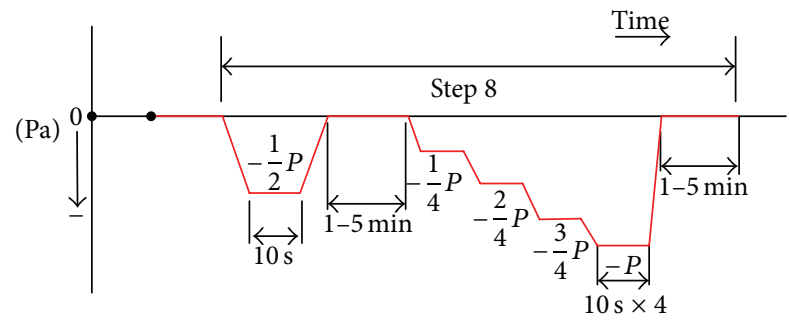

(b)

FIgURE 3: (a) Positive wind pressure intervals and (b) negative wind pressure intervals for wind resistance test.

should not be less than $1 \mathrm{~min}$ or greater than $5 \mathrm{~min}$ at zero loading.

(5) Apply the load in the number of increments specified by the maximum test load, which should not be less than four approximately equal increments. Apply and maintain the full test load for $10 \mathrm{~s}$ unless otherwise specified, and record the related deflection readings (Figure 3(a)).

(6) Release the pressure difference and, after a recovery period, which allows for stabilization, record the permanent deformation. The recovery period for stabilization should not be less than 1 min or greater than $5 \mathrm{~min}$ at zero loading. 


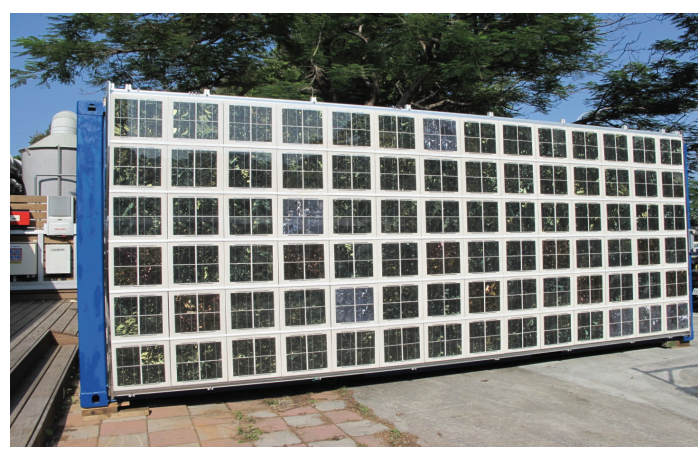

(a)

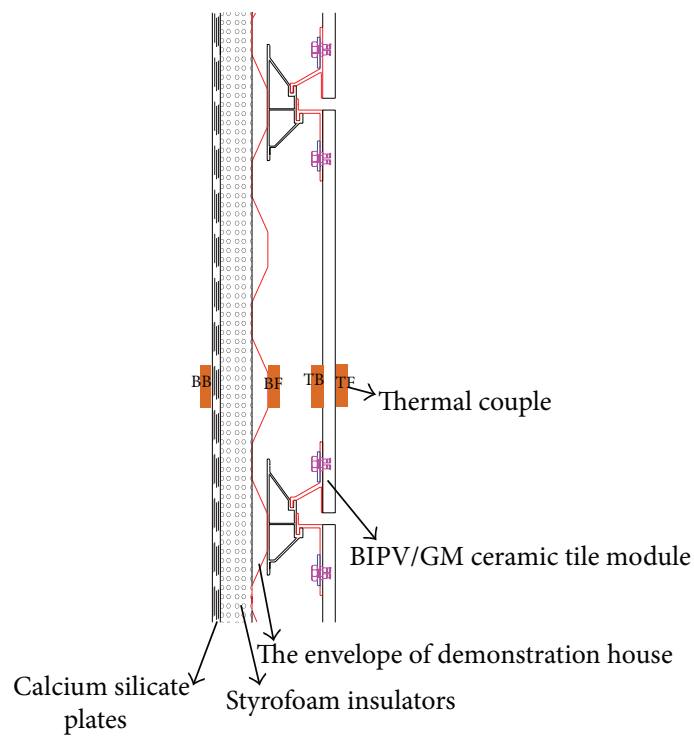

(b)

FIgURE 4: (a) The $1 \mathrm{kWp}$ BIPV system is hung on the vertical wall of the demonstration house, (b) the cross-section structure of the BIPV/GM system.

(7) If the behavior of the specimen under load indicates that sudden failure may occur, which would damage the measuring specimen, the deflection measuring specimen may be removed, and the load should then be continuously increased until the maximum test load or maximum load that can be sustained is reached. At this point, release the load, and, after a recovery period, record the permanent deformation. The recovery period for stabilization should not be less than 1 min or greater than 5 min at zero load.

(8) Repeat steps 4 7 in the reverse loading direction (Figure 3(b)).

2.6. Full-Scale Demonstration House and Electrical Plan. Figures 4(a) and 4(b) show the proposed $1 \mathrm{kWp}$ BIPV system composed of $6 \times 14 \mathrm{PV}$ modules, with each containing $2 \times 2$ solar cell arrays $(40 \mathrm{~cm} \times 40 \mathrm{~cm} \times 12 \mathrm{~mm})$, which is integrated into the vertical wall of the demonstration house. The length, width, and height of the BIPV system are

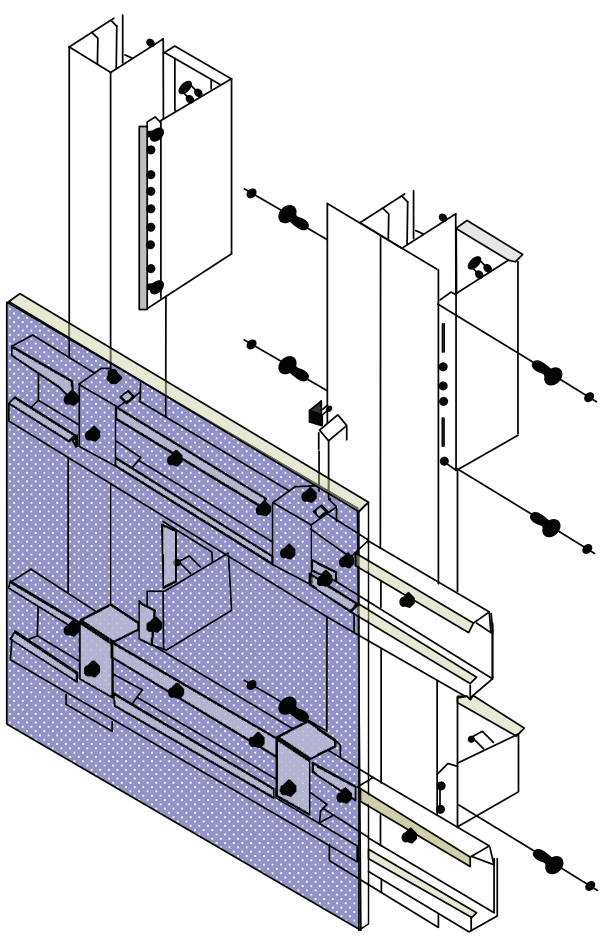

FIgURE 5: Back anchor system.

$604.5 \mathrm{~cm} \times 12 \mathrm{~cm} \times 259 \mathrm{~cm}$, respectively. The demonstration house façade contains a BIPV system, air-gap layer, outer steel frame, $30 \mathrm{~mm}$ Styrofoam insulators, and $9 \mathrm{~mm}$ calcium silicate plates. Four thermal couples are used to measure the temperature on the front side (TF) and back side (TB) of the BIPV system and exterior surface $(\mathrm{BF})$ and interior surface $(\mathrm{BB})$ of the demonstration house. A pyranometer based on ISO 9060 second class [16] is used to sample the irradiation data every ten seconds and every one minute. The BIPV system adopts the novel architectural dry-suspended method, with the back anchor system shown in Figure 5.

Figure 6 shows the electrical-circuit layout of the $1 \mathrm{kWp}$ BIPV/GM system. Each $21 \mathrm{PV}$ modules by shunt winding are connected to a $10 \mathrm{~A}$ no fuse breaker (NFB) switch, which has about $37.8 \mathrm{~V}$ of V-MPP. A $250 \mathrm{~W}$ charge-discharge controller is used for two sets of serial PV modules and twelve $2 \mathrm{~V}$ batteries were charged using the maximum power point tracking (MPPT) solar charge controller. This standalone $\mathrm{BIPV}$ system design is used with a $3 \mathrm{~kW}$ DC/AC electrical transformer, and this electrical plan can output $24 \mathrm{VDC}$ and $110 \mathrm{~V} \mathrm{AC}$ voltage to the loads. The total capacity of the batteries is $13,320 \mathrm{Ah}(26.6 \mathrm{kWh})$, which can supply electrical power for up to 20 hours with a $1 \mathrm{kWp}$ AC load.

\section{Numerical Simulation}

Computer simulations have been shown to be an effective way to evaluate the energy performance of buildings. The computer simulation assessment by the "Autodesk Ecotect Analysis" simulation software carried out in this work analyzes the energy and electrical generation performance of 


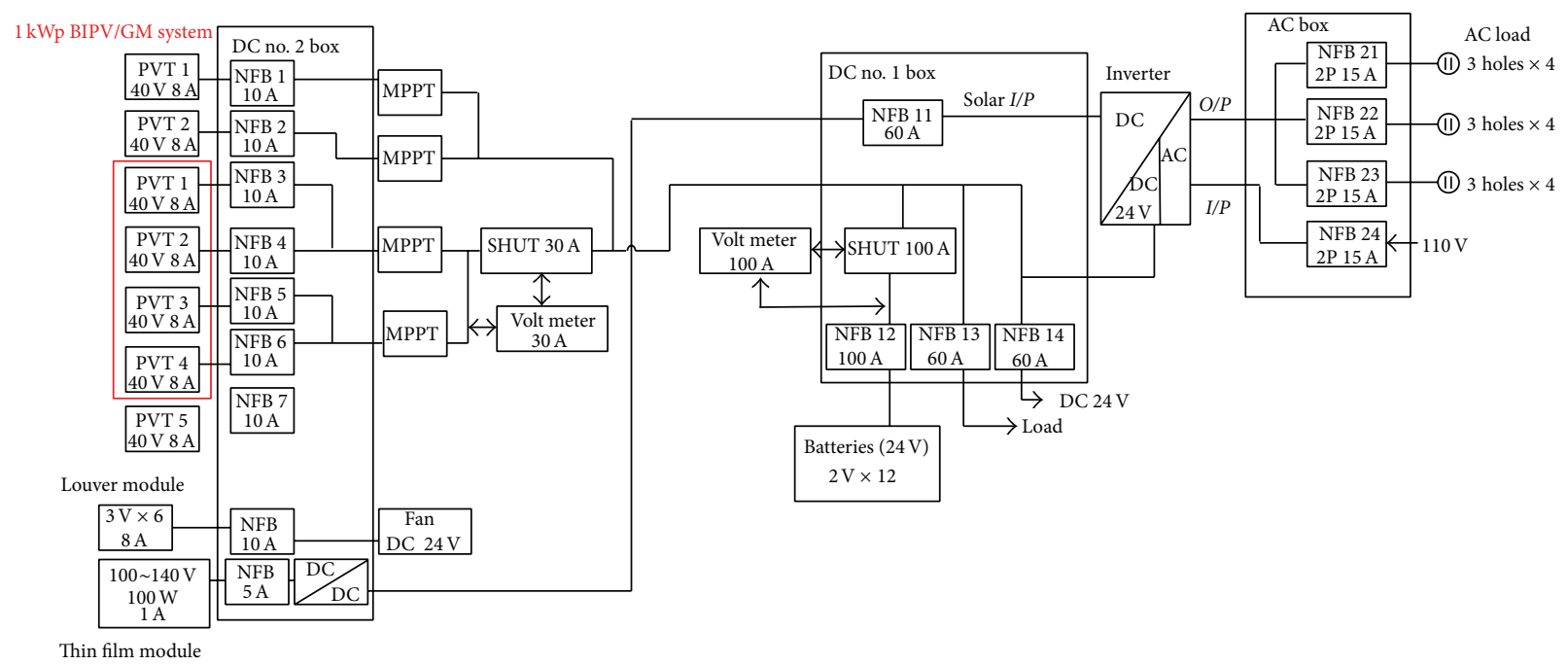

FIgUre 6: The electrical-circuit layout of the $1 \mathrm{kWp}$ BIPV/GM system.

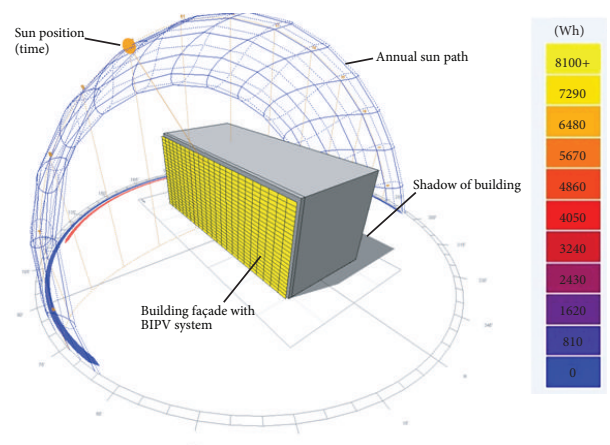

FIGURE 7: The BIM model for the demonstration house.

whole demonstration house integrated with the BIPV system. In order to find the best design of the BIPV systems used on the building's envelope in all directions and also for four vertical walls of the building in this study, we build both a BIPV demonstration house and a simulation model to simulate the performance of electrical power generation. The simulation model is then used to compile and throughput each electrical power generation condition for the BIPV demonstration house design.

In our experiment, the BIPV demonstration house is located in Hsinchu, Taiwan. The simulation model is based on the average weather data for Hsinchu over the last 10 years (2002-2012; Central Weather Bureau, Taiwan). The computational simulation control factors include the solar azimuth, the building location, the distribution of solar irradiation, the temperature variation, and the shading of the BIPV demonstration house. The BIM model of the BIPV demonstration house is shown in Figure 7.

\section{Result and Discussion}

Much of the work to integrate PV modules into the design of buildings has focused on the issues of power generation
TABLE 1: Optical properties of the proposed BIPV.

\begin{tabular}{lc}
\hline & BIPV module \\
\hline UV transmittance & 0 \\
UV reflectivity & 5.40 \\
Visible light transmittance & 0 \\
Visible light reflectivity & 5.45 \\
Solar irradiation transmittance & 0 \\
Solar irradiation reflectivity & 8.45 \\
Solar irradiation absorptivity & 91.55 \\
Emissivity front side (outdoor) & 0.837 \\
Emissivity back side & 0.927 \\
\hline
\end{tabular}

efficiency and thermal performance, with many examples placing the devices on roofs, since this location has greater solar irradiation intensity and less shade. Most PV modules adopt poly- or $\alpha$-Si solar cells to make a trade-off between construction cost and electrical generation. In the experiment carried out in the current study, the BIPV system hangs directly on the vertical wall of a demonstration house, and the shading effect and solar azimuth angle will reduce the system's electrical generation capacity. This work thus adopts single-crystal solar cells combined with a ceramic tile for efficient photoelectron conversion and steady electrical power generation. This approach is based on the ideas presented in Iencinella et al., which integrated thin film $\alpha$-Si solar cells with $10 \mathrm{~cm} \times 10 \mathrm{~cm}$ ceramic tiles [17]. Ceramic tiles are often used as building materials and have the advantages of high porosity and high thermal conductivity. By simultaneously serving as both the building envelope material and a power generation device, the BIPV system presented in the current work can provide savings in both material and electricity costs and add architectural interest to a building.

4.1. Optical Properties. Table 1 shows the optical properties of the proposed PV module. Most solar cells use 


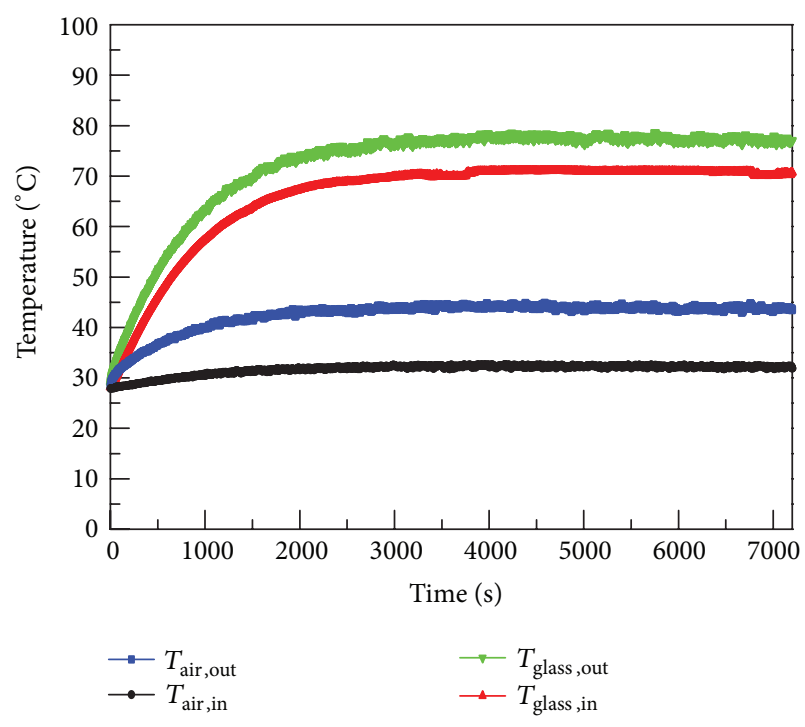

Figure 8: Histories of the surface temperature $\left(T_{\text {glass, out }}\right.$ and $\left.T_{\text {glass, in }}\right)$ and ambient temperature ( $T_{\text {air, out }}$ and $T_{\text {air, in }}$ ) for the proposed PV module.

a double-glazed type of packaging, sandwiched between two sheets of tempered-glass. The solar cells are then serially or shuntly connected by copper conducting wires that go into a connection box. Although BIPV systems that use transparent glass have greater visible light transmittance, they also have poor thermal insulating capabilities and are less safe, due to their greater weight and fragility. This study presented a PV module that is integrated with ceramic tiles and directly hangs on a building's façade using the architectural dry-suspended method, and thus a high visible light transmittance is not required. On the other hand, the high solar irradiation absorptivity and surface emissivity of the proposed PV module can help to achieve more efficient photoelectron conversion.

4.2. Thermal Properties. Figure 8 presents the surface temperature of the exterior and interior sides of the proposed PV module. The steady temperature of exterior surface of $\mathrm{PV}$ module is $72^{\circ} \mathrm{C}$, while that of the other side is $65^{\circ} \mathrm{C}$. The temperature on the exterior surface is greater than that on the interior side because of the high heat-absorptive ability and heat accumulation on the rear of the PV ceramic tile. The lower inside temperature of the PV module can reduce the thermal accumulation that otherwise occurs to decrease photoelectron efficiency of solar cells.

4.3. Electrical Characteristics. Table 2 shows the open circuit voltage $\left(V_{\mathrm{oc}}\right)$, short circuit current $\left(I_{\mathrm{sc}}\right)$, fill factor $(\mathrm{FF})$, and maximum power determination $\left(P_{\max }\right)$ for a conventional $\mathrm{PV}$ module and the proposed PV module. Although the $V_{\text {oc }}$ and $I_{\mathrm{sc}}$ of the proposed PV module are a little lower than those of the conventional module, and the $P_{\max }$ there is $4.6 \%$ lower, the proposed PV module has higher fill factor. Table 3 shows the electrical characteristics of this PV module before and after a 50 thermal cycling test and a $200 \mathrm{~h}$ humidity-freeze
TABLE 2: Results of maximum power determination test.

\begin{tabular}{|c|c|c|c|}
\hline Class: A & STC & $E: 1000 \mathrm{~W} / \mathrm{m}^{2}$ & Temp.: $25^{\circ} \mathrm{C}$ \\
\hline Items & Unit & $\begin{array}{l}\text { Conventional } \\
\text { PV module }\end{array}$ & $\begin{array}{l}\text { Proposed } \\
\text { PV module }\end{array}$ \\
\hline$V_{\mathrm{oc}}$ & {$[\mathrm{V}]$} & 0.62 & 0.61 \\
\hline$I_{\mathrm{sc}}$ & {$[\mathrm{A}]$} & 8.27 & 7.70 \\
\hline$P_{\max }$ & {$[\mathrm{W}]$} & 3.59 & 3.43 \\
\hline $\mathrm{FF}$ & [\%] & 70.33 & 72.93 \\
\hline
\end{tabular}

TABLE 3: Results of maximum power determination test for PV module.

\begin{tabular}{lccc}
\hline $\begin{array}{l}\text { Class: A } \\
\text { Items }\end{array}$ & $\begin{array}{l}\text { STC } \\
\text { Unit }\end{array}$ & $\begin{array}{r}E: 1000 \mathrm{~W} / \mathrm{m}^{2} \\
\text { Before test }\end{array}$ & $\begin{array}{c}\text { Temp.: } 25^{\circ} \mathrm{C} \\
\text { After test }\end{array}$ \\
\hline$V_{\text {oc }}$ & {$[\mathrm{V}]$} & 0.60 & 0.61 \\
$I_{\text {sc }}$ & {$[\mathrm{A}]$} & 7.72 & 7.70 \\
$P_{\max }$ & {$[\mathrm{W}]$} & 3.41 & 3.43 \\
$\mathrm{FF}$ & {$[\%]$} & 72.69 & 72.93 \\
\hline
\end{tabular}

test based on the IEC 61215 standard [15]. The results show that there was no significant decay in terms of the electrical characteristics of the PV module. This indicates that this PV module is suitable for use in the kind of humid weather that is common in Taiwan, which is a subtropical island.

4.4. Wind-Resistance Test. When resistance to severe snow or ice accumulation is required, the IEC-61215 standard states that the front surface pressure of the module should be able to withstand $5400 \mathrm{~Pa}$. The current study thus tested the inward and outward wind resistance up to $6400 \mathrm{~Pa}$, with $2400 \mathrm{~Pa}$ used as the benchmark and $6400 \mathrm{~Pa}$ as the maximum test conditions. This is of practical interest in Taiwan, as the island is often hit by typhoons. The results shown in Table 4 indicate that the PV module suffered from no significant deflection or damage after wind-resistance test. The proposed PV module is thus able to withstand a level 17 typhoon in Beaufort scale.

4.5. Simulation Results. The BIM modeling and energy analysis software is a powerful tool that can be used to effectively predict and simulate the solar cell irradiation intensity and electrical power generation levels in relation to BIPV buildings. Since solar irradiation on the four directions of building façades (north, south, east, and west) varies with the time of a day, this will also affect the level of electrical power generation. Figures $9(\mathrm{a}) \sim 9(\mathrm{~h})$ show the simulation results, based on the annual solar trajectory and solar irradiation intensity, for four façades of the demonstration house at 10 o'clock in the morning and 3 o'clock in the afternoon. And the daily electrical power generation is also shown in Figure 10 for west, east, south, and north cases, and it can be seen that the western facing façade produces the maximum electrical power. In addition, in the western case, the electrical power generation starts at 11 oclock in the morning and lasts until 4 oclock in the afternoon, with the maximum at 2 o'clock. The peak of electrical power generation for the west side of the building is the highest, at around $900 \mathrm{Wh}$ at 2 
TABLE 4: Results of wind resistance test.

\begin{tabular}{|c|c|c|c|c|}
\hline Interval & Wind pressure $(\mathrm{Pa})$ & Maximum deflection & Maximum deflection/span ratio & Visual inspection \\
\hline 01 & +2400 & $0.10 \mathrm{~mm}$ & $1 / 15070$ & No deformation effect \\
\hline 02 & -2400 & $-0.90 \mathrm{~mm}$ & $1 / 1674$ & No deformation effect \\
\hline 03 & +3400 & $1.80 \mathrm{~mm}$ & $1 / 837$ & No deformation effect \\
\hline 04 & -3400 & $-2.00 \mathrm{~mm}$ & $1 / 745$ & No deformation effect \\
\hline 05 & +4400 & $2.30 \mathrm{~mm}$ & $1 / 655$ & No deformation effect \\
\hline 06 & -4400 & $-2.50 \mathrm{~mm}$ & $1 / 603$ & No deformation effect \\
\hline 07 & +5400 & $2.90 \mathrm{~mm}$ & $1 / 520$ & No deformation effect \\
\hline 08 & -5400 & $-3.00 \mathrm{~mm}$ & $1 / 502$ & No deformation effect \\
\hline 09 & +6400 & $3.55 \mathrm{~mm}$ & $1 / 425$ & No deformation effect \\
\hline 10 & -6400 & $-3.80 \mathrm{~mm}$ & $1 / 397$ & No deformation effect \\
\hline
\end{tabular}

o'clock in the afternoon. The south side of the building has a longer electrical generation time than the east and west sides. However, the peak of electrical power generation for the south side is only about $280 \mathrm{Wh}$, which means that this side has a lower solar irradiation intensity over a day. Further, the northern facing façade has the lowest electrical power generation, since Taiwan is in the Northern Hemisphere. In summary, the western façade of the building has the greatest electrical power generation of the four cases examined in this work. The results of this simulation can help in the development of an experimental BIPV demonstration house that faces towards the west and thus generates the most electrical power.

Table 5 lists the monthly electrical power generation results for a whole year, with these being $443.1 \mathrm{kWh}$, $443.5 \mathrm{kWh}, 438.6 \mathrm{kWh}$, and $47.8 \mathrm{kWh}$ for the east, west, south, and north cases, respectively. These results indicate that when the BIPV system faces east, west, or south, it can produce almost the same amount of electrical power. The total annual BIPV power output from the western side of the building is a little higher $(0.4 \mathrm{kWh})$ than that from the eastern and southern sides and almost 10 times greater than that on the northern side. This reveals that the direction that a building façade faces is an important factor with regard to solar irradiation intensity and thus the resulting electricity generation potential.

Figure 11 shows the monthly electrical generation (kWh) of a BIPV system for the building model facing in all four directions. Interestingly, although the east, west, and south cases produce almost the same amount of electrical power, the distribution of electrical power generation over time varies for each direction. For the east and the west cases, the most electrical power is generated in the summer, and for the south it is in the winter period. This information can be used to design more effective BIPV systems that can provide a steady supply of power throughout the year.

4.6. Demonstration House Performance. The BIPV system developed in this work using the architectural dry-suspended method is hung directly on the vertical wall of the demonstration house facing west, with an air gap between the BIPV system and the wall to provide natural ventilation. Good thermal dissipation thus occurs on the back side of the
TABLE 5: Simulation results for monthly electrical power generation.

\begin{tabular}{lcccc}
\hline Month & $\begin{array}{c}\text { East } \\
(\mathrm{kWh})\end{array}$ & $\begin{array}{c}\text { West } \\
(\mathrm{kWh})\end{array}$ & $\begin{array}{c}\text { South } \\
(\mathrm{kWh})\end{array}$ & $\begin{array}{c}\text { North } \\
(\mathrm{kWh})\end{array}$ \\
\hline January & 18.075 & 16.748 & 49.297 & 0.223 \\
February & 17.893 & 15.013 & 45.315 & 0 \\
March & 22.947 & 23.085 & 38.750 & 0 \\
April & 35.784 & 32.245 & 27.051 & 0.400 \\
May & 44.128 & 47.530 & 9.186 & 6.415 \\
June & 59.503 & 55.811 & 1.852 & 17.459 \\
July & 72.133 & 64.637 & 4.883 & 18.269 \\
August & 64.150 & 62.341 & 24.486 & 5.011 \\
September & 42.896 & 47.421 & 47.085 & 0.093 \\
October & 28.200 & 35.602 & 60.505 & 0 \\
November & 22.065 & 26.178 & 72.440 & 0 \\
December & 15.372 & 16.919 & 57.802 & 0 \\
\hline Annual total & 443.146 & 443.530 & 438.652 & 47.870 \\
\hline
\end{tabular}

BIPV system, which can modulate the indoor temperature of the building. Furthermore, the use of the architectural dry-suspended method means that buildings can be easily retrofitted and the BIPV system can be easily maintained.

Figure 12 shows the temperature distribution of the demonstration house and the ambient temperature $\left(T_{a}\right)$, with the daily measurements taken from 8:00 to 17:00. The results indicate that there is no significant variation in temperature between the exterior and the interior surfaces of the demonstration house during 8:00 10:00, because the solar radiation intensity is less than $100 \mathrm{~W} / \mathrm{m}^{2}$ before $10: 00$ a.m. This result is the same as that seen in the simulation data, as shown in Figure 10, for the case when the façade faces west. The simulation data show that both electricity generation and solar irradiation intensity increase from 11 oclock in the morning until 4 o'clock in the afternoon. As the solar irradiation intensity increases over time, the BIPV system starts to generate electrical power, although the temperature on the exterior surface of the demonstration house is still about $10^{\circ} \mathrm{C}$ lower than that on the front side of the BIPV system. This good insulating effect can ascribe to the high thermal inertia of ceramic tiles and the architectural drysuspended method adopted for the BIPV system. This BIPV 


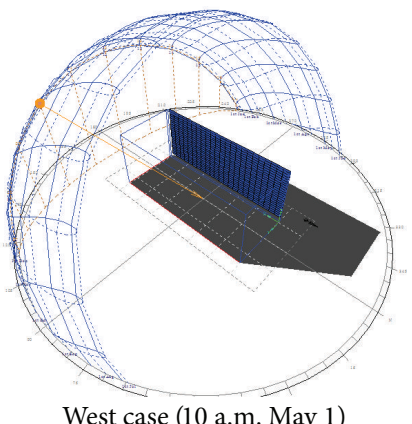

(a)

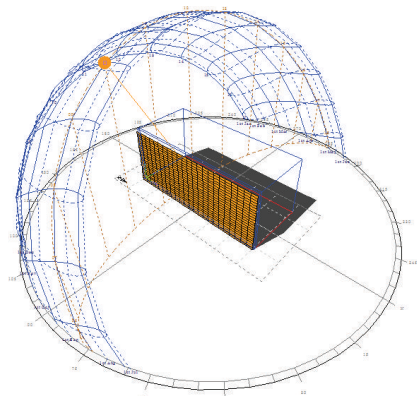

East case (10 a.m. May 1)

(c)

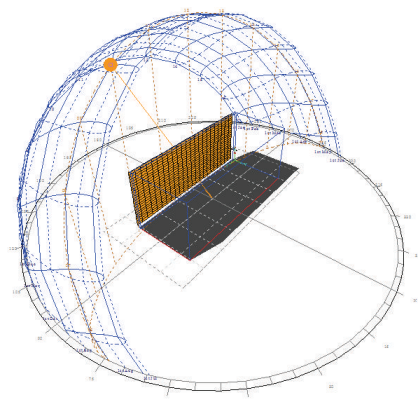

South case (10 a.m. May 1)

(e)

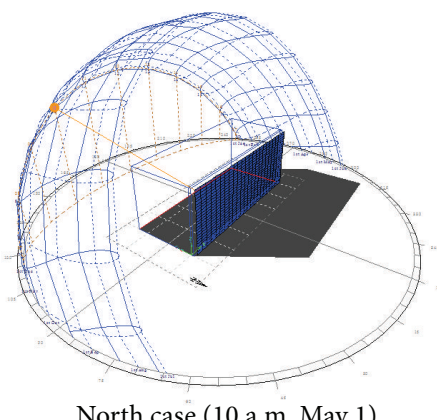

(g)

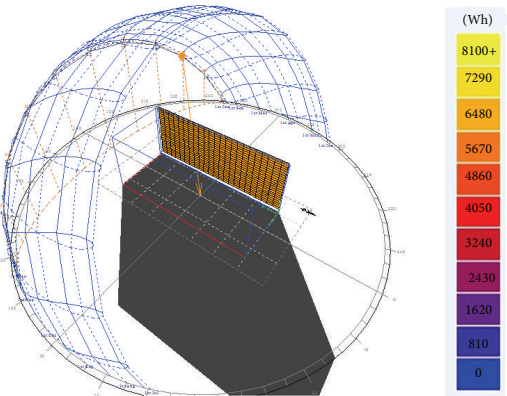

West case (3 p.m. May 1)

(b)

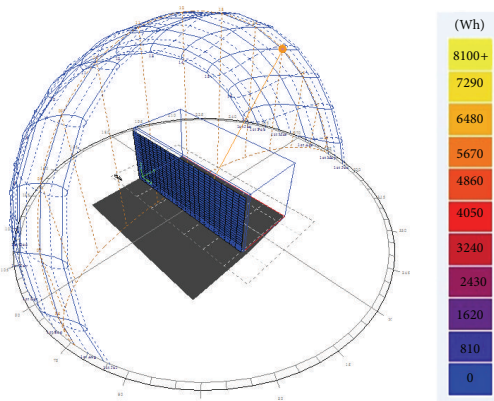

East case (3 p.m. May 1)

(d)

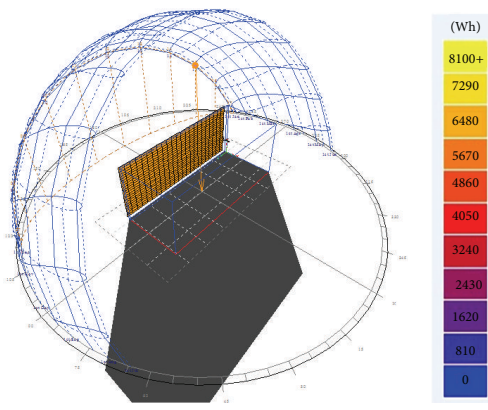

South case (3 p.m. May 1)

(f)

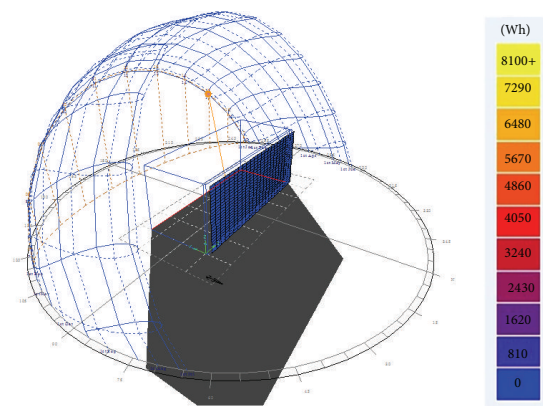

North case (3 p.m. May 1)

(h)

Figure 9: Solar trajectory and irradiation intensity of (a), (b) west, (c), (d) east, (e), (f) south, and (g), (h) north cases.

system can thus isolate the heat from solar irradiation and modulate the indoor temperature. In addition, there is also an air gap between the BIPV system and the vertical wall that facilitates natural ventilation, which can also reduce thermal accumulation and the temperature of the back of the BIPV system. An infrared thermoimaging instrument (NEC, TVS200ES) was used to examine the temperature distribution of the BIPV system. Figure 13 shows the surface temperature 


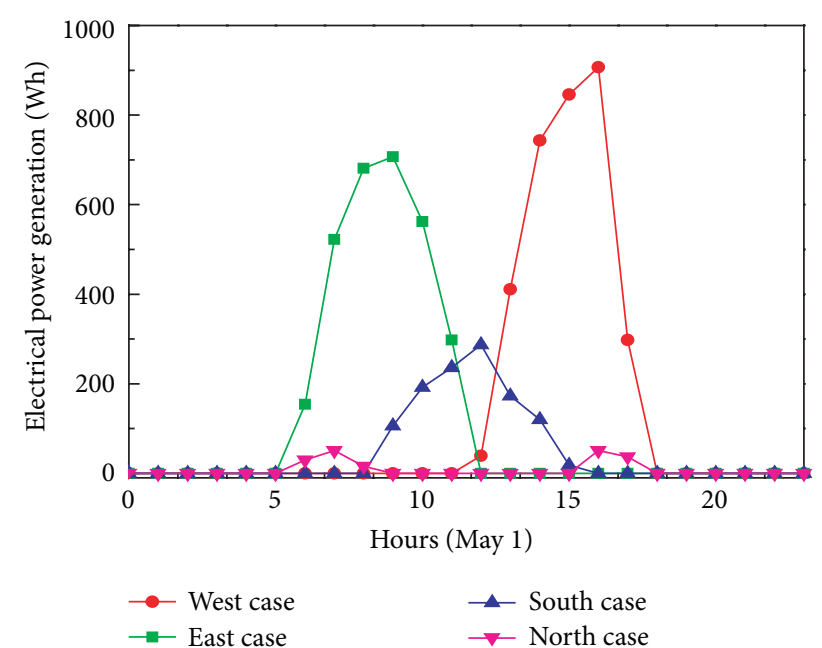

FIGURE 10: Daily electrical power generation of west, east, south, and north cases.

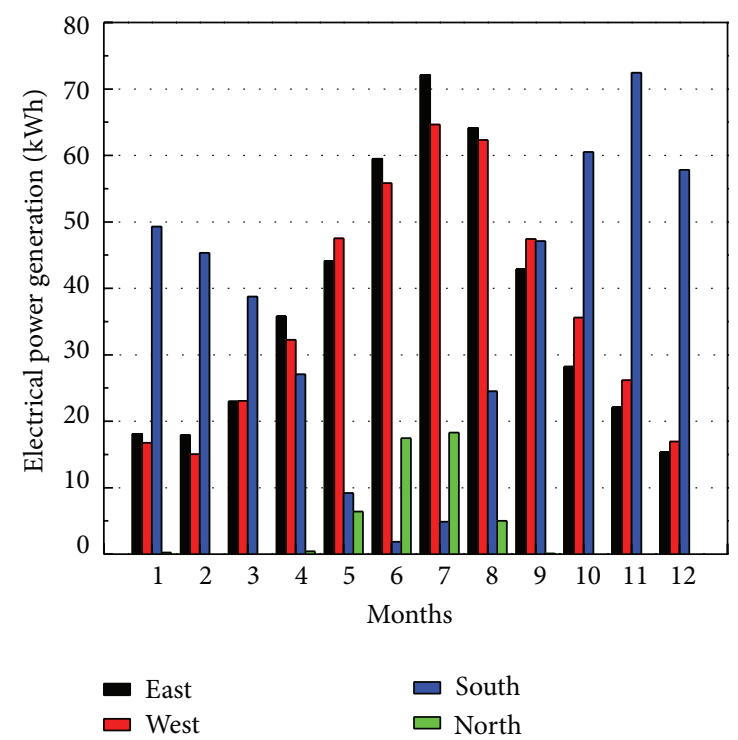

FIGURE 11: The monthly electrical output (kWh) of the BIPV for the building model facing in all four directions.

distribution of the BIPV system at 14:00. The results indicate that the distribution on the perpendicular surface of the BIPV system is almost uniform, and the temperature difference from top to bottom is about $2^{\circ} \mathrm{C}$. Since the proposed BIPV system is hung perpendicularly on the vertical wall of the demonstration house, this variation in temperature is caused by different solar azimuth angle and thus changes in the solar irradiation intensity.

Table 6 shows the accumulated electrical power generated by the proposed BIPV demonstration house over six months, with the result being $185 \mathrm{kWh}$. Figure 14 compares the experimental and simulated electrical power generation data for the period from October, 2012, to March, 2013. The trend of the simulation is consistent with the experimental results, although the former underestimates the latter by

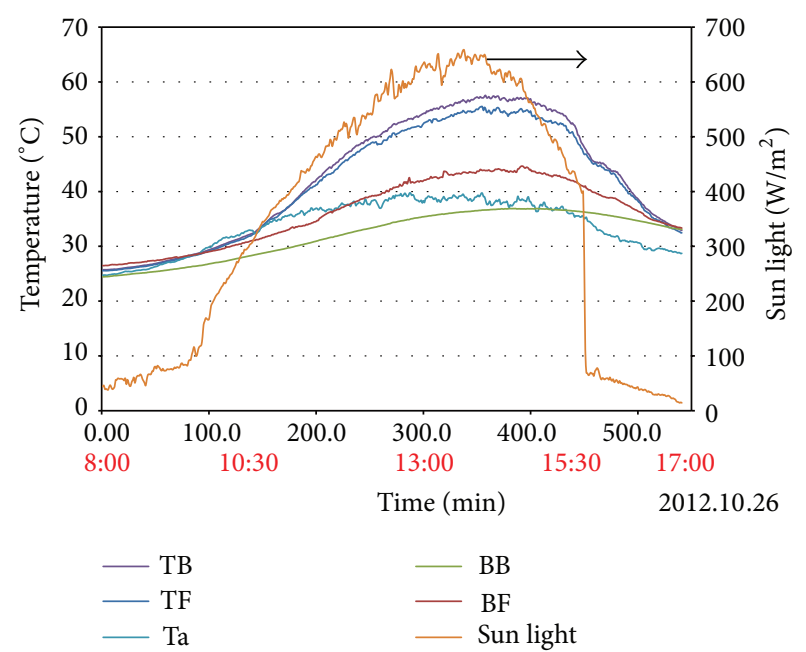

Figure 12: Temperature measurement of the BIPV system.

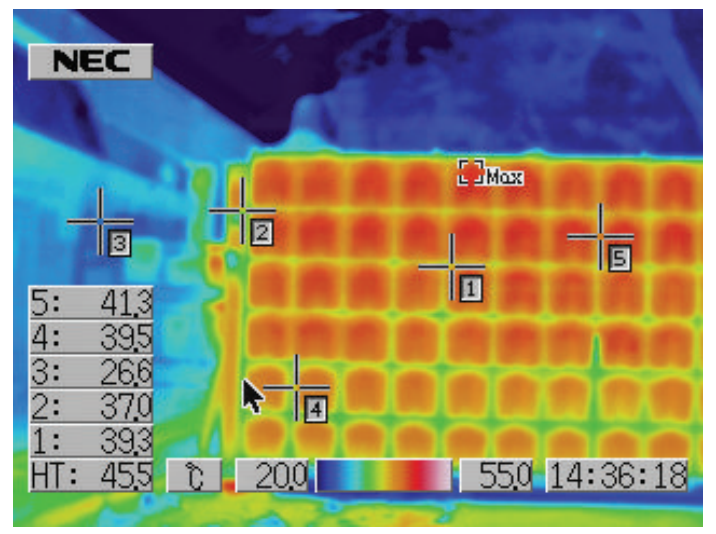

Figure 13: Temperature distribution of the BIPV system.

about $27 \%$, which is greater than the difference reported in an earlier study, which underestimated the power generation by about $20 \%$ [18]. However, since the data obtained in the current study show a good fit between the trends from the simulated and experimental data, the findings of this work can be used to predict the electrical generation performance of versatile BIPV systems and thus improved the design of this technology.

\section{Conclusions}

The concepts of net zero energy, zero energy, and passive energy are becoming more important as part of the energy conservation policies adopted by the building construction industry. BIPV systems can be integrated into buildings in order to save energy, reduce installation costs, and modulate the indoor temperature.

This work presented a PV ceramic tile that can prevent thermal accumulation and add aesthetic interest to a building's façade. In addition, the architectural dry-suspended method that is used to install this system can enhance the efficiency of natural ventilation. The results of a 50 
TABLE 6: Electrical power accumulation for the six-month experimental monitoring.

\begin{tabular}{lc}
\hline Experimental period & Electrical power generation $(\mathrm{kWh})$ \\
\hline October 1-October 31, 2012 & 53 \\
November 1-November 30, 2012 & 26 \\
December 1-December 30, 2012 & 26 \\
January 1-January 31, 2013 & 28 \\
February 1-February 28, 2013 & 22 \\
March 1-March 31, 2013 & 30 \\
\hline Total & 185 \\
\hline
\end{tabular}

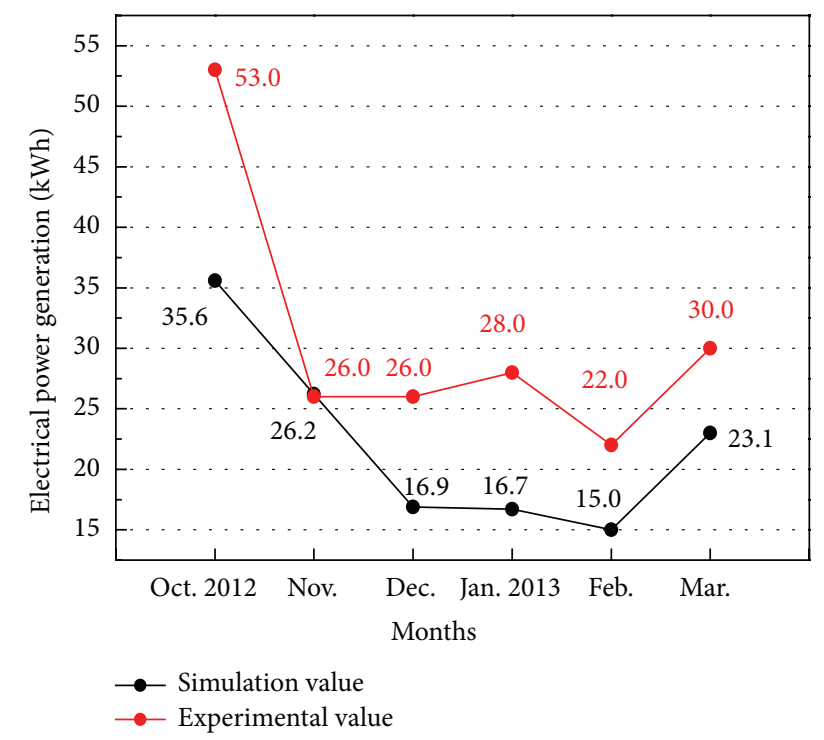

FIGURE 14: Comparison of electrical generation results from the simulation and experiment.

thermal cycling test, a $200 \mathrm{~h}$ humidity-freeze test, and a windresistance test show that the proposed BIPV system is strong enough to withstand typhoons and a humid climate, both of which are common in Taiwan. In addition, Autodesk software was used to carry out a BIM modeling and energy analysis of the BIPV demonstration house. The results of the simulation have a very similar trend with regard to the level of electrical power generation as the six-month experimental data that was obtained from October, 2012, to March, 2013. This data can be used to improve the design of BIPV systems, making them more efficient and cheaper. The results of the experiments showed that the proposed BIPV system was able to generate an accumulated $185 \mathrm{kWh}$ electricity over a sixmonth period and thus can replace a significant amount of the electricity that would otherwise be generated by burning fossil fuels. This paper thus provides valuable information for renewable energy planners and architectural designers who are interested in using BIPV systems.

\section{Conflict of Interests}

The authors declare that there is no conflict of interests regarding the publication of this paper.

\section{Acknowledgment}

The authors would like to thank the financial support from the Bureau of Energy, Taiwan.

\section{References}

[1] McKinsey \& Company, Pathways to a Low-Carbon Economy. Version 2 of the Global Greenhouse Gas Abatement Cost Curve, McKinsey \& Company, 2009.

[2] M. Raugei and P. Frankl, "Life cycle impacts and costs of photovoltaic systems: current state of the art and future outlooks," Energy, vol. 34, no. 3, pp. 392-399, 2009.

[3] S. Strong, "Building Integrated Photovoltaics (BIPV), Whole Building Design Guide," June 2010, http://www.wbdg.org/ resources/bipv.php.

[4] H. J. Chen, C. M. Chiang, C. M. Shu, and S. K. Lee, "Self -power consumption research with the thermal effects and optical properties of the HCRI-BIPV window system," Journal of Electronic Science and Technology, vol. 10, no. 1, pp. 29-36, 2012.

[5] J. J. Kim, S. K. Jung, Y. S. Choi, and J. T. Kim, "Optimization of photovoltaic integrated shading devices," Indoor and Built Environment, vol. 19, no. 1, pp. 114-122, 2010.

[6] C. Peng, Y. Huang, and Z. Wu, "Building-integrated photovoltaics (BIPV) in architectural design in China," Energy and Buildings, vol. 43, no. 12, pp. 3592-3598, 2011.

[7] J. Yoon, J. Song, and S. J. Lee, "Practical application of building integrated photovoltaic (BIPV) system using transparent amorphous silicon thin-film PV module," Solar Energy, vol. 85, no. 5, pp. 723-733, 2011.

[8] S. Wittkopf, S. Valliappan, L. Liu, K. S. Ang, and S. C. J. Cheng, "Analytical performance monitoring of a $142.5 \mathrm{kWp}$ grid-connected rooftop BIPV system in Singapore," Renewable Energy, vol. 47, pp. 9-20, 2012.

[9] Í. P. D. Santos and R. Rüther, "The potential of buildingintegrated (BIPV) and building-applied photovoltaics (BAPV) in single-family, urban residences at low latitudes in Brazil," Energy and Buildings, vol. 50, pp. 290-297, 2012.

[10] J. Yoon, S. Shim, Y. S. An, and K. H. Lee, "An experimental study on the annual surface temperature characteristics of amorphous silicon BIPV window," Energy and Buildings, vol. 62, pp. 166175, 2013.

[11] American Society for Testing and Materials, ASTM E330-02: Standard Test Method for Structural Performance of Exterior Windows, Doors, Skylights and Curtain Walls by Uniform Static Air Pressure Difference, Philadelphia, Pa, USA, 2002.

[12] A. Porwal and K. N. Hewage, "Building Information Modeling (BIM) partnering framework for public construction projects," Automation in Construction, vol. 31, pp. 204-214, 2013.

[13] ISO 9050, Glass in Building-Determination of Light Transmittance, Solar Direct Transmittance, Total Solar Energy Transmittance, Ultraviolet Transmittance and Related Glazing Factors, International Organization for Standardization, Geneva, Switzerland, 2003.

[14] G. Alvarez, M. J. Palacios, and J. J. Flores, "A test method to evaluate the thermal performance of window glazings," Applied Thermal Engineering, vol. 20, no. 9, pp. 803-812, 2000.

[15] International Electrotechnical Commission, CEI/IEC 61215: Crystalline Silicon Terrestrial Photovoltaic (PV) ModulesDesign Qualification and Type Approval, International Electrotechnical Commission, Geneva, Switzerland, 2nd edition. 
[16] ISO 9060, Solar Energy-Specification and Classification of Instruments for Measuring Hemispherical Solar and Direct Solar Radiation, International Organization for Standardization, Geneva, Switzerland, 1990.

[17] D. Iencinella, E. Centurioni, and M. Grazia Busana, “Thin-film solar cells on commercial ceramic tiles," Solar Energy Materials \& Solar Cells, vol. 93, no. 2, pp. 206-210, 2009.

[18] L. Maturi, W. Sparber, B. Kofler, and W. Bresciani, "Analysis and monitoring results of a BIPV system in northern Italy," in Proceedings of the 25th European Photovoltaic Solar Energy Conference and Exhibition, and the 5th World Conference on Photovoltaic Energy Conversion, Valencia, Spain, September 2010. 

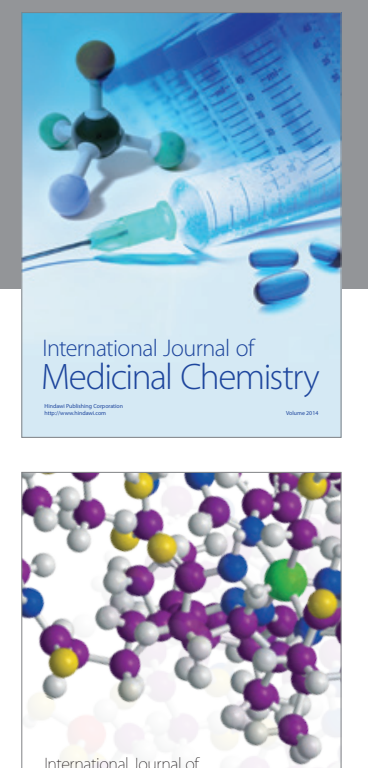

\section{Carbohydrate} Chemistry

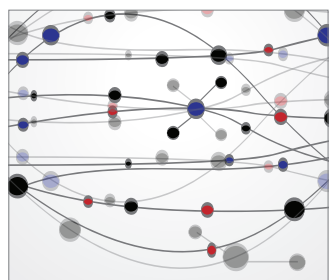

The Scientific World Journal
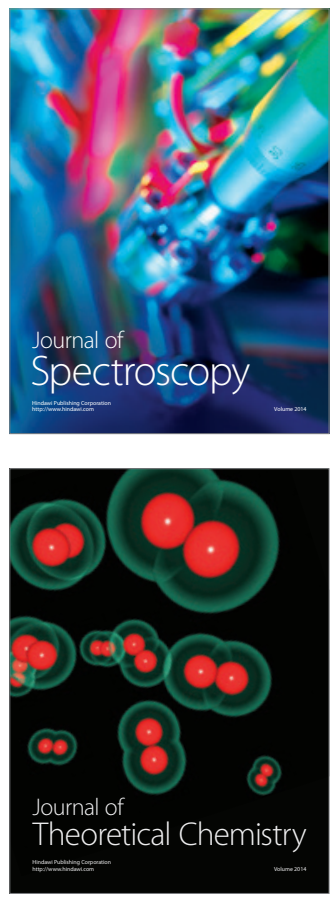
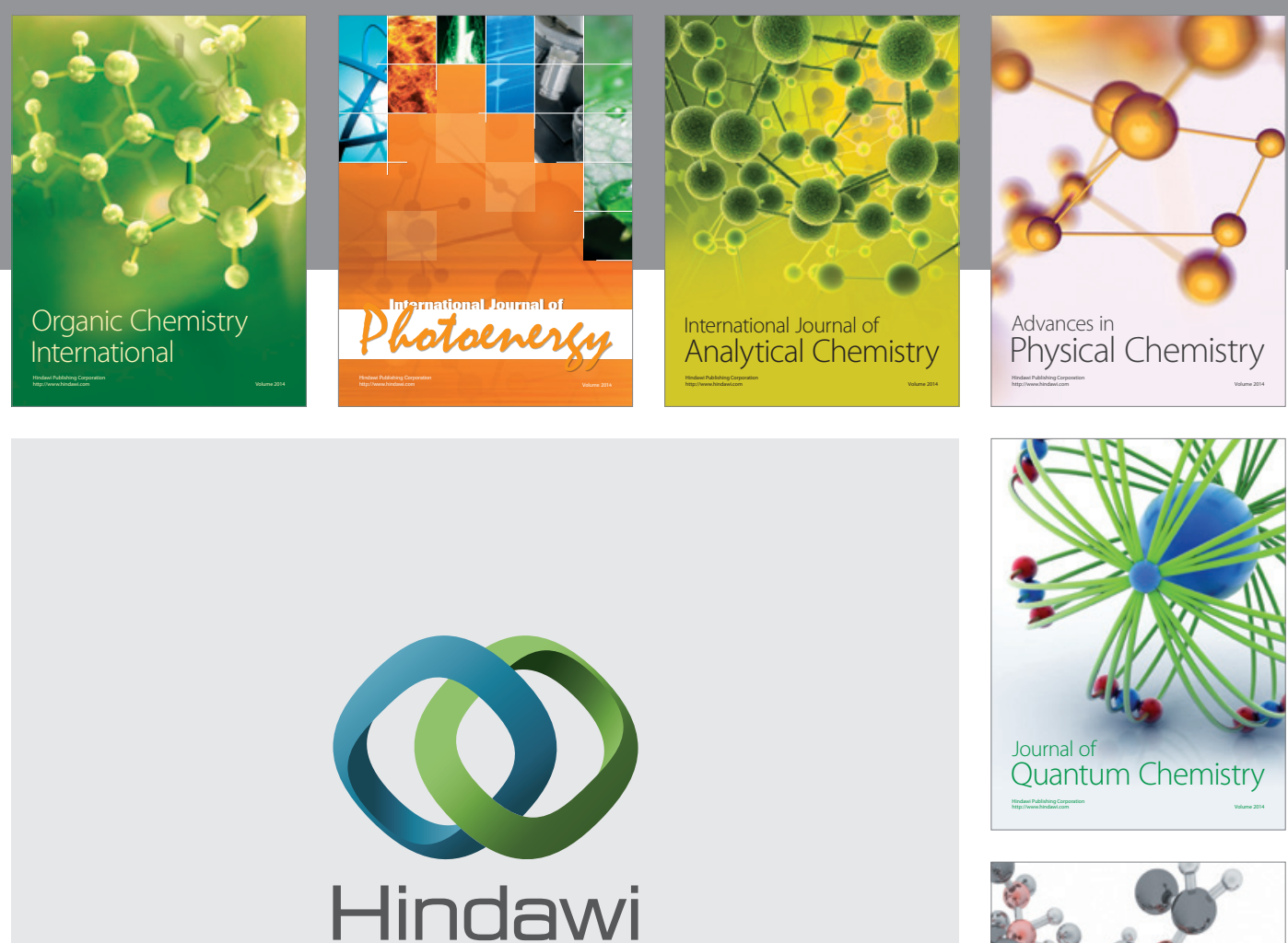

Submit your manuscripts at

http://www.hindawi.com

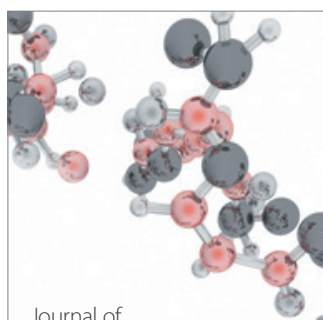

Analytical Methods

in Chemistry

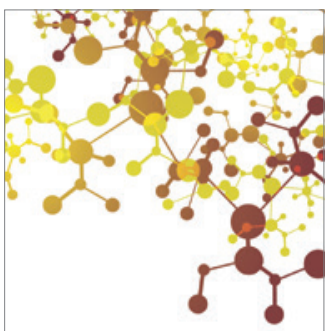

Journal of

Applied Chemistry

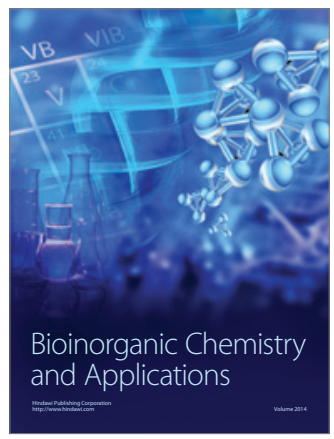

Inorganic Chemistry
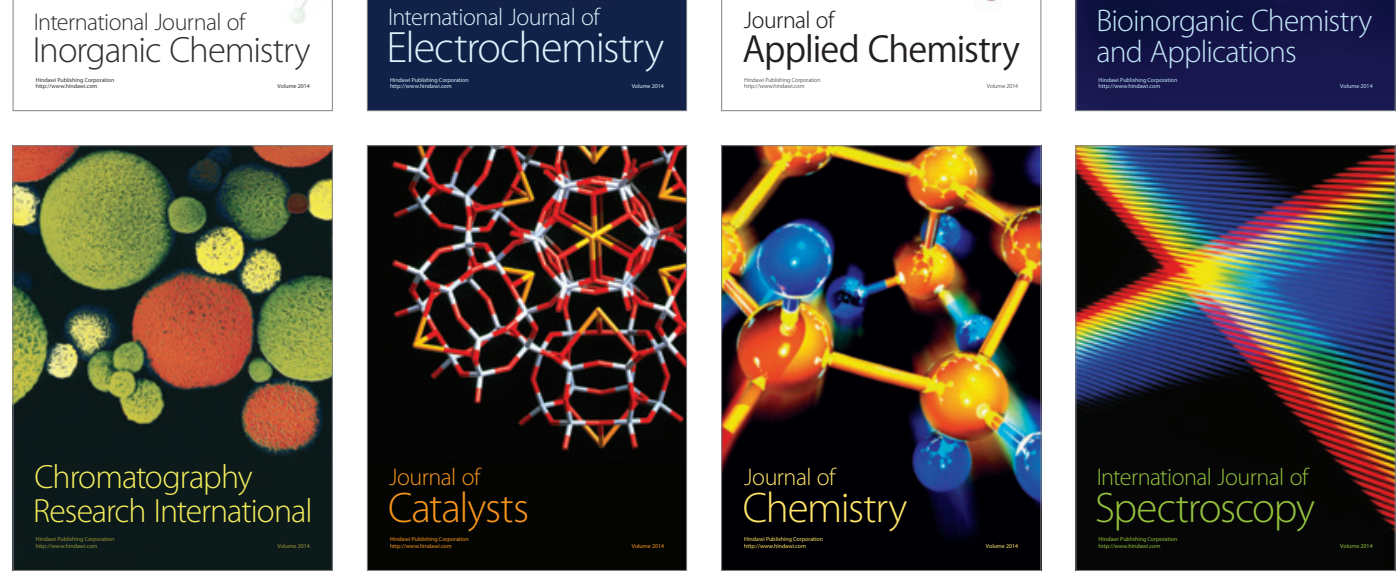